\title{
Michał NOWOSIELSKI
}

State University of Applied Sciences in Płock https://orcid.org/0000-0001-7383-4872

\section{EUROPEAN SECURITY ISSUES AS SEEN BY POLISH PARLIAMENTARIANS ${ }^{1}$}

At the heart of Poland's security policy lies the stability of Eastern Europe. The international community was severely disrupted by the Ukrainian armed conflict, which became an utmost challenge for the European Union member states, already overwhelmed by the eurozone debt crisis, the fallout of Brexit, a massive influx of migrants from the Middle East and Africa and President Donald Trump administration's befuddling policy towards Europe. The Ukrainian conflict has been equally challenging for the North Atlantic Alliance. Russia's annexation of Crimea and its meddling with the internal Ukrainian conflict by backing separatists in Donbas put into question NATO's ability to deliver collective defense. This further aggravated the fundamental dilemma over whether it is sensible to allow NATO to continue its operation and how the Alliance should handle its strategic overstretching and reconcile conflict management on a global scale with the need to renew its original function of collective defense.

For Poland, escalating security problems in Eastern Europe pose a direct existential threat in the form not only of an imminent military conflict but, above all, of political and economic instability in the region, mainly in Ukraine, and energy insecurity. These factors, resulting from Poland's geopolitical location, make the country consider NATO's ability to defend its members to be paramount. This does not mean that Poland underestimates the threats to the EU and its cohesion that result from the illegal influx of refugees, the destabilization of the Middle East and international terrorism.

The article attempts to explore the views of Polish parliamentarians on threats to the security of Europe and the EU and their implications for Poland and its relations with Germany in the context of the Ukrainian conflict, NATO transformations, divergent energy interests and the refugee crisis. It examines the responses of Polish Parliamentarians to a dual survey carried out in 2015 and 2016 within the framework of the project "Views of the Polish political elite on Poland's relations with Germany within the European Union." The surveys used close-ended questions and involved two distinct groups (selected due to the respondents' reluctance to participate in the

${ }^{1}$ The paper is the outcome of a research project funded by the National Science Center (Poland) entitled „The Polish political elites vs. Poland's relations with Germany within the European Union” under appriopration decision no DEC-2012/07/B/HS5/03966. 
study, the need to ensure anonymity, and the fact that, conducted in the spring of 2015 and in the spring of 2016, the study coincided with the end of the parliamentary term of office). The respondents had been members of the Polish Parliament and Members of the European Parliament either before or during the study. Requests to complete the survey were put to members of parliamentary committees on foreign and European affairs and security, members of the Polish-German parliamentary group, all Polish MEPs, as well as former MPs. The questionnaire was completed by 22 respondents in the first and 21 respondents in the second survey. The respondents represented diverse political parties (Civic Platform, Law \& Justice, Democratic Left Alliance, Polish People's Party).

\section{POLAND'S STANCE ON THE UKRAINIAN CONFLICT}

For Poland, Ukraine's independence and democratization posed a geostrategic challenge. One premise of Poland's eastern policy was to give Ukraine priority over Russia (Żurawski vel Grajewski, 2014). This defined views on the association of Ukraine and other Eastern European states (such as Georgia) with Western institutions (the EU and NATO). In line with its prevailing geostrategic interests, Poland favored accepting Ukraine and Georgia into the North Atlantic Alliance and offering it the prospect of EU membership. Poland's key Western partners discounted both options as contrary to their priority of nurturing the relationship with Russia. Hence, Ukraine and Georgia were treated, at best, as partners in the European Neighborhood Policy (Gromadzki, 2014).

After the failure of the Vilnius Eastern Partnership summit of November 13, 2013 and the Kiev civil protests, attempts to avert the Ukrainian crisis were made jointly by foreign ministers of Poland, Germany and France with the agreement of February 21, 2014. In late January and early February 2014, Prime Minister Tusk strove to get the member states of the EU to respond firmly to the Ukrainian crisis, in line with Poland's policy precepts whereby an effective policy hinged on the broad engagement of the EU and on Warsaw's commitment to shaping the EU's Eastern European policy.

As of the summer of 2014, Poland found itself no longer involved in the negotiations regarding the Ukrainian conflict, which had since been conducted in the Normandy format. The Polish news media and experts concluded that it was Germany, using its diplomatic channels, that effectively excluded Poland from the talks. The opposition pinned blame for the alleged failure of Polish diplomacy on Minister Sikorski. In their view, Poland lost its status as a partner in resolving Eastern European issues, and had its position vis-à-vis Russia repudiated by Germany (Cichocki, 2014; Buras, 2014).

In 2014-2015, the prevailing position among decision-makers was that the current policy was well-advised and deserved to be supported. Both Prime Minister E. Kopacz's administration and Prime-Minister-B.-Szydło-led Law-\&-Justice-party government, which was established in the late 2015, spoke in bleak terms about the Ukrainian conflict and its implications for Poland's security. After Russia became a greater military threat to Poland, Poland needed to build up its armaments capacities, tighten bilateral military cooperation with the US and bring NATO to step up its engagement 
in Central and Eastern Europe and in Poland in particular. The view that Russia was Poland's main threat and adversary grew stronger (Stolarczyk, 2016: 143).

During the Ukrainian conflict, Poland was unseated by Germany as a promoter of Ukraine's interests in the EU. Germany's leadership manifested itself through efforts to resolve the conflict and stabilize Central and Eastern Europe. In February 2015, the Merkel government brought the parties to the conflict to conclude an agreement (the so-called Minsk II), making Germany the main actor in Europe's eastern policy at the expense of the EU, whose significance declined (Malinowski, 2015a: 29-30). At the time of the eastern Ukrainian conflict, Poland began to lose its influence on Western policy towards Ukraine. The Polish government's tactics of normalizing relations with Russia, adopted particularly in 2009-2011 along with its concept of using the Eastern Partnership to extend influence in the post-Soviet territory, turned out to be a failure (Foks, 2014: 123; Bielecki, 2015).

\section{POLAND ON STRENGTHENING NATO'S EASTERN FLANK}

The Russian threat made NATO's security guarantee for Poland particularly relevant. Poland and Germany differed in their assessment of security threats (Buras, 2014a: 5). In its security policy, Poland sought to strengthen NATO's allied defense and proposed to have NATO troops permanently deployed in the Eastern European Member States of the EU. In Germany's view, having NATO follow this path would breach the Founding Act on Mutual Relations, Cooperation and Security between NATO and the Russian Federation (Erler, 2014). The Merkel government believed that the Founding Act would provide more room for maneuver in negotiations with Russia. The Act was considered a cornerstone of both Germany's policy in the Alliance and its relations with Russia (Busse, 2014). Polish experts criticized Germany's opposition as a sign of an insufficient understanding of Poland's legitimate security interests (Kuźniar, 2014). As a consequence, bilateral co-operation between Poland and the United States returned to the forefront. The two countries launched a joint Partnership Solidarity Program, which further tightened their military cooperation.

For strategic reasons, Poland was compelled to adopt the conclusions of NATO's Newport summit of September 4-5, 2014. It was seriously alarmed by the ambivalent views of the German public regarding Russia, the EU's sanction policy and NATO's security agenda. In addition, the problems experienced by the Bundeswehr could prevent Germany delivering on its allied commitments under art. 5. They adversely affected Polish-German relations (Cichocki, 2014). Against this background, the Polish political elite became highly sensitive to Germany's readiness to again assume the role of an advocate of Russian interests, were Russia to request such assistance. After all, Germany presumed that the Ukrainian conflict could only be resolved with, but never against Russia.

In 2014-2015, the positions of the governments and the public of Poland and Germany differed significantly in the level of anxiety they expressed regarding the imminent military threat posed by Russia. In their exposés, Foreign Minister Radosław Sikorski (8 May, 2014) (Ministry of Foreign Affairs, 2014) and his successor Grzegorz 
Schetyna (6 November 2014) (Ministry of Foreign Affairs, 2015) named Russia as the main threat to Polish and international security in the context of the Ukrainian conflict. Never since 1989 have Polish security policy decision-makers expressed their concerns over the immediate military threat posed to Poland by Russia as strongly as they did in 2014-2015 (Stolarczyk, 2016: 135).

In 2014, 2015 and the early 2016, the West German government again opposed the permanent stationing of NATO troops in Central and Eastern Europe. Its views stood in stark contrast to those of the Polish government, which believed the agreement was no longer in force after it had been breached by Russia (Malinowski, 2015c: 45). During President Duda's visit to Germany on August 28, 2015, Chancellor Merkel criticized Poland's demands to establish permanent NATO bases in Poland and the Baltic states (Stolarczyk, 2016: 145). The position of the German government, which opposed setting up permanent NATO bases in Poland and the Baltic States, was supported by the vast majority of German society, driven mainly by the desire not to provoke Russia (Kühn, 2016).

\section{POLAND'S POSITION ON THE EUROPEAN UNION'S ENERGY SECURITY}

Poland's dependence on Russian energy supplies is a major factor for its security and foreign policy priorities (Energy Security of Poland, 2016: 18). For Poland, the security of supply has become a key energy security consideration, whereas Germany tends to see supplies in the context of the effectiveness of the energy policy, the stability of economic growth, and economic relations with Russia.

Poland found Angela Merkel's government's support for the Nord Stream pipeline to be totally unacceptable (B. Nowak, 2014: 41 et seq.). Such support was expected to cast Germany in a prominent role in the distribution of Russian supplies to other European countries.

The Ukrainian conflict made some German politicians keenly aware of the risks to which their country exposed the EU by making Russia the main gas supplier of the Member States and by Germany itself assuming the role of the main intermediary in conveying such supplies to the rest of union. The Ukrainian conflict confirmed Poland's arguments on the enormous potential threats associated with Russia's use of gas supplies to Europe as a political tool.

In his 2014 campaign to have the EU member states establish an energy union in response to the Ukrainian conflict, Prime Minister Tusk sought to strengthen the EU's negotiating position vis-à-vis Russia, limit Gazprom's influence and put a stop to the Nord Stream project that harmed Poland's interests. Tusk's proposal focused, among others, on having the 28 Member States purchase gas jointly, adopting solidarity mechanisms to support countries threatened by the withholding of gas supplies, and financing key gas development projects in the Member States that depended most heavily on Gazprom supplies. Poland's position was clear: excessive dependence on Russia weakened Europe (Ruszel, 2015: 393). Meanwhile, Germany exploited the cooperation of energy companies to cushion the effects of the Ukrainian crisis and strived to secure gas supply 
solutions that would benefit the German economy by e.g. effectively blocking Poland's proposals (Formuszewicz, 2015: 76). The European Commission substantially curtailed Tusk's plan in the spring of 2015 (Malinowski, 2015b: 259). Germany found Poland's main postulate of jointly purchasing fuels to be unacceptable.

\section{MIGRATION CRISIS}

The positions of the two Polish governments led by Ewa Kopacz (2014-2015) and Beata Szydło (2015-2017) on how to resolve the migration crisis, evolved between 2015 and 2017. Both governments favored better protection of the external borders of the Schengen Area and the delivery of assistance in the migrants' countries of origin. They opposed the EU's imposition of refugee quotas on individual states. After some hesitation and against the opinions of other Visegrad Group countries, the Kopacz administration joined the EU relocation program. Prime Minister Kopacz emphasized that Poland would accept refugees only but not economic migrants from the Middle East and North Africa (Stolarczyk, 2017: 31). In the run-up to the Parliamentary elections of October 25, 2015, Poland engaged in a heated debate on refugees and migrants. During its early months in power, the Beata-Szydło-led Law-\&-Justice government reneged on campaign promises and refrained from questioning the agreed refugee quotas. After the Brussels terrorist attacks of March 22, 2016, Prime Minister Szydło's government pulled out of Kopacz administration's commitment to admit 7,000 refugees within two years and opposed any other quota system. This decision was motivated by both security concerns and the desire, fueled by rising anti-Muslim sentiments in Polish society, to protect civilizational heritage and national identity. At the time, Poland and other Visegrad Group countries came under severe criticism from both France and Germany for their failure to show solidarity in the migration crisis (Stolarczyk, 2017: 32).

\section{OPINIONS OF MEMBERS OF THE POLISH PARLIAMENT - PRESENTATION OF RESULTS}

\section{The Ukrainian crisis}

The respondents were asked to name what they thought would be the impact of the Ukrainian conflict on Poland. The vast majority of them (14 out of 20) believed that if the conflict continued, it would deteriorate the prospects of pursuing Poland's eastern policy. Aligned with this opinion was the view, shared by the majority of the respondents (14 out of 20), that the conflict would destabilize the post-Soviet states and widen divides among EU Member States (14 out of 20). The respondents diverged on whether Russia would increase its domination in the post-Soviet area and whether the chances for a pro-western reorientation of Ukraine would be improved ( 8 for and 9 against; 10 for and 8 against, respectively). 
Asked which specific actions Poland should take to best respond to the Ukrainian conflict, the majority of the surveyed chose creative solutions, and specifically launching action for Ukraine within the EU (18 out of 21), bringing Ukraine into the EU's sphere of influence (15), and supporting a policy of sanctions against Russia (13).

The respondents overwhelmingly disapproved of the controversial Normandy format (with only 3 of them supporting its use). However, they were deeply divided on whether to include Poland among the negotiating states ( 9 of them favoring the solution). None of the respondents agreed that Russia's sphere of influence should be accepted. Only one person believed that Poland should support the majority position of the EU member states. Only one respondent also conceded that the EU member states should be urged to seek a compromise with Russia at any cost.

Another group of questions concerned Germany taking over the leadership in the EU's effort to tackle the Ukrainian conflict. The respondents agreed largely (17 out of 21 respondents who answered this question) that such leadership was made possible through the weakness of the EU's foreign and security policy. A smaller number of respondents thought it resulted from France and the United Kingdom having grown weaker (6 respondents) or from Germany having gained the support of the United States ( 7 respondents). Asked about the implications of Germany taking the lead in the EU effort to resolve the Ukrainian conflict, as many as 12 out of 21 respondents pointed to the strengthening of Germany's overall position as the most likely consequence. The second survey produced a similar result as more than a half(11) of the MPs asked about the consequences of Germany's engagement in resolving the Ukrainian conflict for the country's position in the EU predicted its strengthening. Meanwhile, 9 respondents believed such engagement would have no impact.

The respondents were divided on the importance of Germany's leadership for resolving the conflict. 7 of them thought allowing Germany to assume this role would impede the resolution of the conflict due to the country's overly forbearing approach to Russia. Others (5) were of the opinion that Germany would contribute to an effective resolution of the Ukrainian conflict as a country with which Russia is the most likely to reckon.

The respondents also assessed the implications of German leadership for Poland. Their answers varied. Some respondents conceded that Poland would benefit from Germany's position and commitment to resolve the conflict. They noted that Germany would help stabilize and reconstruct Ukraine (8 respondents), and curb Russia's expansion (7). Others (8 respondents) predicted that Poland would suffer from the effects of Germany's leadership because Germany's priority was to maintain good relations with Russia at all costs. Six respondents felt that Germany would contribute to limiting Poland's influence in Ukraine. The majority of the surveyed (16 of 21) were confident that Germany would be interested in cooperating with Poland in implementing the eastern policy. These, however, could not agree on Germany's motivations behind such an interest. The majority of them stressed that Poland could legitimize Germany's leadership in the EU (10 respondents). Other suggested motives included Germany's recognition of Poland's aspiration to play a role in shaping the EU's eastern policy (9), Germany's acceptance of Poland as a natural ally in the matters of Eastern Europe (8), Germany's recognition of Poland's competence on the EU's eastern policy (6), its intention to influence Polish initiatives in Eastern Europe (6) and its desire to strengthen cooperation with Poland within the EU (6). 
Only 5 respondents were of the opinion that Germany would not be interested in collaborating with Poland on eastern policy. They suggested that Poland was an awkward partner for Germany as it complicated Germany's relations with Russia (4 respondents), or that it served as a natural competitor to Germany in Eastern Europe. None of the surveyed agreed that Poland was too weak a partner to attract Germany's interest.

The outcomes of the second survey on the benefits to be garnered by Poland as a result of the role assumed by Germany have been largely consistent with the opinions expressed in the first survey. 9 respondents believed that Germany's involvement in Ukraine would benefit Poland, 8 thought it would be harmful while 6 felt it would make no difference for Poland's position. The respondents also expected Polish-German cooperation on eastern policy to become closer ( 6 respondents), looser (6 respondents) or unchanged ( 9 respondents).

\section{NATO security policy}

Asked about the consequences of the Ukrainian conflict and the spread of ISIS, the majority of the respondents (17 out of 20) agreed that the threats would prompt NATO to upgrade its capabilities to engage militarily in crisis areas and drive the US to maintain and even expand its presence in Europe (the view was supported by 15 respondents and denied by 4). On the other hand, the respondents largely rejected the alternative position that growing threats in Europe's neighborhood would drive the Union to create a European army (6 respondents out of 18). The second survey was consistent with these results. Responding to the same question, all of the surveyed (21) found that the above-mentioned factors (including the Ukrainian conflict) would bring the member states to collaborate more closely within NATO.

Of much significance for determining the MPs' views on NATO and the use of military power were their responses regarding the best way to react to crises and conflicts. The vast majority of the respondents (20 out of 21 ) considered the strengthening of NATO to be the most essential objective. Contrasted with this were responses regarding Poland's active engagement in allied operations (supported by merely 10 respondents). Similarly as in the previous question about the consequences of regional conflicts, the respondents showed reluctance to subscribe to Poland's support for the strengthening of the CSDP (13 responses) and its involvement in the debate on establishing a European army (9). However, only one respondent believed that Poland should not engage in allied operations of various kinds and suggested that its priority should be to defend its own territory. Only 5 respondents agreed that, faced with crises and regional conflicts outside of Europe, Poland should declare its support for but refrain from engaging in allied operations. The second survey confirmed these respondent preferences. All of the surveyed (21) suggested that Poland should continue its effort to strengthen NATO. More respondents (15) advocated strengthening the CSDP, and most importantly, many more respondents than in the first survey (17 people, with 4 voting against!) favored active engagement in NATO military operations. The same number of respondents (9) agreed that Poland should contribute to the debate on establishing a European army. 
A priority in Poland's security policy is to ensure the constant presence of NATO troops in the country. A question was asked about the consequences of Germany's opposition to such presence for Poland's security. The majority of the surveyed MPs (15 out of 21) believed that the German government weakened Poland's security. However, several of them agreed that such opposition was inconsequential in view of the (future) rotational presence of NATO troops in Poland.

The MPs (4, with 16 disagreeing) also acknowledged that Germany's support for CSDP expansion was unlikely to make the CSDP more important than NATO in crisis response. The respondents were divided on whether Germany's advancement of CSDP expansion would harm Poland's security. 11 of them, with 7 disagreeing, supported the view that this would have little impact on Poland's security, which was guaranteed by NATO, not the EU. Many respondents (8, with 11 disagreeing) believed this would even strengthen Poland's security.

However, Germany's opposition to the permanent NATO presence in Poland did not prevent the respondents ( 20 out of 21 ) from believing that Germany would be interested in military cooperation with Poland. The respondents were nevertheless divided on why Germany would show such interest. Over a half of the respondents (11 out of the 19 respondents who answered this question) agreed this was due to Poland serving as an important geopolitical buffer that protected Germany from threats from the east.

A similar number of respondents agreed with the other two statements suggesting that the two states shared a number of security objectives. 7 respondents were of the opinion that Polish-German cooperation might be driven by Germany's alignment with Poland on the need to strengthen NATO and secure the US presence in Europe, whereas 8 respondents subscribed to the view that both countries recognized the need to develop the CSDP. Only one person did not think that Germany would be interested in collaborating with Poland in the field of security, the purported reason for this being that the strengthening of NATO's eastern flank, as postulated by Poland, would complicate Germany's relations with Russia. The second survey included a question about the possible future course of Polish-German cooperation in the sphere of security. The majority of the respondents (11) believed such cooperation would not change, 8 thought it would deepen, while only 2 believed it would become weaker.

\section{Energy security}

Another security factor in Eastern Europe that is of essential importance for Poland is close cooperation between Germany and Russia in the field of energy. Asked about mid- and long-term prospects for such cooperation, more than a half of the respondents (11) said it would diminish, while the remaining 5 felt it would be tightened, with another 5 suggesting it would remain unchanged. As for the consequences of such cooperation for Germany, the surveyed offered varying answers. 6 agreed it would make Germany dependent on Russia, 7 suggested the opposite implications, while 5 foresaw no impact. Regarding the consequences of German-Russian energy cooperation for Poland, the surveyed members of the Polish political elite were more explicit: 13 of 
the respondents thought the consequences would be negative, 5 believed they would be positive, and 3 suggested no impact.

One of the concepts promoted by Poland in 2014 to alter the EU's energy policy and improve energy security in Eastern Europe was to establish an energy union. Asked about the consequences of setting it up, the majority of the respondents suggested the union would boost Poland's energy security in the gas sector (17 out of 25) and make Poland immune to the uncertainties of gas supply from the east (10 respondents).

\section{Migration crisis}

The link between the refugee crisis and Polish-German relations was evident. Germany promoted a relocation system and pushed Poland to accept its share of refugees. This issue became the foremost reason why Polish-German relations deteriorated early during the rule of the Law and Justice party.

The vast majority of the MPs surveyed in the second survey (16) expected the refugee crisis to hurt Germany (with 3 respondents disagreeing and 2 suggesting no impact either way). The members of the Polish parliament saw the matter as a driver of EU disintegration. The belief was shared by more than a half of the respondents (12), while as many as 6 expected this would contribute to the emergence of a hard core of the EU, which would be harmful to Poland. A small minority of 3 respondents maintained that European integration would remain unaffected.

The study also included an assessment of the influence of the refugee crisis on Germany's position in the EU. The majority of the respondents felt such a position would be either weakened (9) or unaffected (8), while a substantial minority claimed that the crisis would strengthen Germany (4).

The respondents differed widely in their opinions on the implications of the refugee crisis for Polish-German relations, believing that the German policy of accepting refugees would either deteriorate the relationship (11) or have no effect (10).

$$
* * *
$$

Opinions on the Ukrainian conflict were consistent across party lines. The majority of the first survey respondents expected the Ukrainian conflict to harm Poland. They rightly believed that, should the conflict continue, it would make it harder for Poland to pursue its eastern policy and further destabilize the region, causing a rift among the EU Member States. Members of the Polish political elite were not quite as clear on the impact the conflict would have on Russia and Ukraine itself.

The recommendations offered by the respondents were also largely consistent regardless of party affiliations. The surveyed suggested that Poland should be proactive within the EU by launching activities for Ukraine, encouraging Ukraine and other post-Soviet states to engage with the EU and supporting sanctions against Russia. The respondents also agreed that the Normandy format was against Poland's interests. However, fewer than a half of the surveyed believed that Poland should be included in the negotiations. 
The respondents also appreciated the importance of Germany's involvement in the Ukrainian conflict. The majority of the first survey participants shared the opinion that Germany's rise to significance was an immediate consequence of the weakness of the EU's foreign and security policy. This, said many of the respondents, would further strengthen Germany's position. The surveyed disagreed on whether Germany's leadership in the resolution of the Ukrainian conflict would benefit Poland. However, asked about the future of the Polish-German cooperation on the EU's Eastern policy, the majority of the first survey respondents said that Germany would be interested in cooperating with Poland. The second survey respondents turned out to be more cautious. The majority of them believed there would be no impact on such relations while the others disagreed as to whether the collaboration would become stronger or weaker. This may be evidence of a relatively strong non-partisan belief in Poland's role as a coarchitect of the EU's Eastern policy.

The majority of the first survey respondents believed that threats to EU's security (the Ukrainian conflict, Russia's military involvement, the spread of the Islamic State, and the war in Syria) would strengthen transatlantic cooperation (bolstering NATO and US presence in Europe). Where the MPs saw eye to eye on the need to strengthen NATO (and not the CSDP), their consensus was undermined by a relatively large number of them refusing to support involvement in military alliances. All of the respondents in the second survey agreed that conflicts and threats in Europe's neighborhood would strengthen cooperation in NATO.

As regards Polish-German security relations, the respondents shared the view that Germany's opposition to the permanent presence of NATO troops in Poland would undermine Poland's security and that no alternative solutions (such as the rotating presence of NATO troops in Poland and stronger Polish-German military cooperation) could remedy the problem. However, the respondents were largely confident that Germany would be interested in cooperating with Poland in the field of security, although the reasons they quoted for such an interest varied widely. The overwhelmingly positive response regarding the prospects for such cooperation again revealed a solid consensus across party lines. The response may be considered surprising in view of the state of political relations between Poland and Germany, which have deteriorated significantly since the autumn of 2016.

The key reason for the decline in German relations was the relocation of refugees, which most of the surveyed MPs considered to be a disintegrating factor and a driver of the loss of cohesion in the EU.

\section{REFERENCES}

Bielecki J. (2015), Potrzebne nowe otwarcie, "Rzeczpospolita", 2.01.

Buras P. (2014a), Die ukrainische Krise, die polnische Außenpolitik und die deutsch-polnischen Beziehungen, "Polen-Analysen", No. 146, 03.06.

Buras P. (2014), Has Germany sidelined Poland in Ukraine crisis negotiations?, 27th August, ECFR.

Busse N. (2014), Nato-Russland-Grundakte. Eine Absichtserklärung - mehr nicht, "Frankfurter Allgemeine Zeitung", 4.09. 
Cichocki M. A. (2014), Bój o wiarygodność Niemiec, "Rzeczpospolita", 14.10.

Erler G. [wywiad] (2014), Rosja bardzo nas rozczarowała, “Gazeta Wyborcza”, 09.12.

Foks R. (2014), Polska i Niemcy a polityka wschodnia Unii Europejskiej, „Dyplomacja i Bezpieczeństwo", No. 1.

Gromadzki G. (2014), Polska wobec kryzysu ukraińskiego, „Biuletyn Niemiecki”, nr 46, 30.04.

$\mathrm{http} / /$ www.ecfr.eu/article/commentary_has_germany_sidelined_poland_in_ukraine_crisis_negotiations301 (29.01.2018).

Informacja Ministra Spraw Zagranicznych o zadaniach polskiej polityki zagranicznej w 2014 roku przedstawiona w Sejmie w dniu 8 maja 2014 r. przez Radosława Sikorskiego, http://www. msz.gov.pl/pl/aktualnosci/wiadomosci/informacja_ministra_spraw_zagranicznych_o_zadaniach_polskiej_polityki_zagranicznej_w_2014_roku (29.03.2017).

Kühn O. (2016), Jeder dritte Deutsche fürchtet Krieg mit Russland, „Frankfurter Allgemeine Zeitung" 26.10 .

Kuźniar R. (2014), Newport: The Summit marked with important anniversaries, "Rzeczpospolita", 27.08, http://www.rp.pl/artykul/1136289.html?print=tak\&p=0 (29.01.2018).

Malinowski K. (2015a), Polityka Niemiec wobec Europy Wschodniej: Russia first?, "Przegląd Politologiczny", No. 4.

Malinowski K. (2015b), Polska - Niemcy w Europie (2004-2014), Poznań.

Malinowski K. (2015c), Stosunki polsko-niemieckie i europejskie kryzysy, "Studia Środkowoeuropejskie", No. 2.

Minister Grzegorz Schetyna o priorytetach polskiej dyplomacji, https://www.msz.gov.pl/pl/ aktualnosci/wiadomosci/minister_grzegorz_schetyna_o_priorytetach_polskiej_ dyplomacji (29.03.2017).

Ruszel M. (2015), Wptyw Polski na ksztaltowanie polityki energetycznej Unii Europejskiej, in: Dziesięć lat członkostwa Polski w Unii Europejskiej. Próba bilansu i nowe otwarcie, (ed.) J. Fiszer, Warszawa.

Stolarczyk M. (2016), Możliwości współdziałania Polski i Niemiec w zakresie ich polityki wobec Rosji i Ukrainy, "Krakowskie Studia Międzynarodowe" (XIII), No. 3.

Stolarczyk M. (2017), Stanowisko Polski wobec kryzysu migracyjno-uchodźczego Unii Europejskiej, „Krakowskie Studia Międzynarodowe” (XIV), No. 2.

Żurawski vel Grajewski P. (2010), Geopolityka - siła - wola. Rzeczpospolitej zmagania z losem, Kraków.

\begin{abstract}
The article attempts to explore the views of the Polish parliamentarians on threats to the security of Europe and the EU and their implications for Poland and its relations with Germany in the context of the Ukrainian conflict, NATO transformations, divergent energy interests and the refugee crisis. We follow the hypothesis, that the opinions on the threats and conflicts in the neighborhood of Europe were consistent across party lines in Europe's neighborhood and they suggest a strong consensus on the necessity to strengthen the cooperation in NATO. The article examines the responses of members of the Polish parliament (members of parliamentary committees on foreign and European affairs and security, members of the Polish-German parliamentary group) and all Polish members of the European Parliament to a dual survey carried out in 2015 and 2016. The questionnaire was completed by 22 respondents in the first and 21 respond-
\end{abstract}


ents in the second survey. The respondents represented diverse political parties (Civic Platform, Law \& Justice, Democratic Left Alliance, Polish People's Party).

Keywords: Europe's security, Poland's security, polish political elite

\section{SPRAWY BEZPIECZEŃSTWA EUROPEJSKIEGO W OPINIACH POLSKICH PARLAMENTARZYSTÓW}

\section{STRESZCZENIE}

Artykuł jest poświęcony przeanalizowaniu poglądów polskich parlamentarzystów w sprawach zagrożeń dla bezpieczeństwa w Europie oraz ich implikacji dla Polski i jej stosunków z Niemcami w kontekście konfliktu na Ukrainie, przemian w NATO, rozbieżnych interesów w dziedzinie energii i kryzysu uchodźczego. Celem jest weryfikacja hipotezy, że opinie na temat zagrożeń i konfliktów w sąsiedztwie Europy były spójne w poprzek podziałów partyjnych i sugerują występowanie silnego konsensu w sprawie konieczności wzmocnienia współpracy w ramach NATO. Artykuł analizuje odpowiedzi członków polskiego parlamentu (członków komisji spraw zagranicznych i ds. Unii Europejskiej Sejmu i Senatu, członków polsko-niemieckiej grupy parlamentarnej) i wszystkich polskich członków Parlamentu Europejskiego w ramach podwójnego badania przeprowadzonego w 2015 i 2016 r. Kwestionariusz został wypełniony przez 22 respondentów w pierwszym i $21 \mathrm{w}$ drugim badaniu. Respondenci reprezentowali różne partie polityczne (Platforma Obywatelska, Prawo i Sprawiedliwość, Sojusz Lewicy Demokratycznej, Polskie Stronnictwo Ludowe).

Słowa kluczowe: bezpieczeństwo Europy, bezpieczeństwo Polski, polskie elity polityczne 